\title{
Sessenta anos depois: a narrativa de um migrante sobre ausência e saudades da família
}

SIXTY YEARS LATER: THE NARRATIVE OF A MIGRANT ON ABSENCE MISSING THE FAMILY

\begin{abstract}
(1)
Marilda A. Menezes

Professora visitante nacional sênior do Programa de Pós-Graduação em Ciências Humanas e Sociais (PCHS) da Universidade Federal do ABC (UFABC/CAPES). Professora do Programa de Pós-Graduação em Ciências Sociais Universidade Federal de Campina GrandePB (PPGCS/UFCG), pesquisadora do CNPq. menezesmarilda@gmail.com

\section{Jurani O. Clementino}

Doutorando do Programa de Pós-Graduação em Ciências Sociais da Universidade Federal de Campina Grande-PB (PPGCS/UFCG). juraniclementino@hotmail.com
\end{abstract}

Recebido em 14 de maio de 2014. Aprovado em 21 de novembro de 2014

\section{Resumo}

Apresentamos aqui um relato da experiência migratória de Ramiro Jordão, que migrou aos 17 anos e perdeu o contato com sua família por seis décadas. Em 2013, ele retornou de São Paulo para encontrar seus familiares que residem em Campina Grande, Paraíba. Pretendemos compreender como Ramiro narra a experiência de migrar e o relacionamento com sua família. Para tanto, nos fundamentamos na metodologia da História Oral. O relato que serve de base para o presente artigo é resultado de uma entrevista com Ramiro gravada digitalmente, com uma hora e cinco minutos de duração. Em sua narrativa, ele elabora uma compreensão de que o longo tempo de ausência da família não significou uma perda da relação afetiva. Em seu relato destacam-se os sentimentos de saudade, sofrimento e tristeza.

Palavras-chave: Migração e família. Narrativas. Sentimentos e identidades. História Oral. 


\section{Abstract}

We present here a report of the migratory experience of Ramiro Jordão, who migrated at the age of 17 and lost contact with his family for six decades. In 2013, he returned from São Paulo to meet his relatives that live in Campina Grande, Paraíba. We seek to understand how Ramiro narrates the experience of migrating and the relationship with his family. For this purpose, we are based on the methodology of Oral History. The report that is the basis of this article is the result of a digitally recorded interview with Ramiro, with the duration of one hour and five minutes. In his narrative, he develops an understanding of the long time absent from the family did not mean a loss of affective relationship. In his report the feelings of longing, suffering and sadness.

Keywords: Migration and family. Narratives. Feelings and identities. Oral History.

\section{Introdução}

Nesse artigo pretendemos compreender a experiência migratória de Ramiro, nascido no município de Queimadas, Paraíba, no ano de 1936. Em 1953, quando tinha 17 anos, ele migrou para a cidade do Rio de Janeiro e trabalhou na área de construção civil, tendo exercido a mesma atividade em São Paulo posteriormente. Em função das difíceis condições de transporte e comunicação entre as regiões Nordeste e Sudeste na época, principalmente nas décadas de 1950 e 1960, ele perdeu o contato com sua família. Durante 60 anos conviveu com esse sentimento de ausência. Entre os anos de 2012 e 2013, um de seus quinze irmãos conseguiu, através de um contato via rede social com um dos filhos de Ramiro, localizá-lo em Boituva, município do interior de São Paulo. Em outubro de 2013, Ramiro retornou para encontrar sua mãe e familiares que residem em Campina Grande.

A informação, especialmente aquela veiculada pela grande mídia, tem assumido papel importante no cotidiano das pessoas. Em muitos casos, é através da televisão ou do rádio que as pessoas tomam conhecimento do que está acontecendo no mundo, em sua cidade ou região. Tomamos conhecimento da história de Ramiro através de informações veiculadas pela mídia local. ${ }^{1}$ As notícias destacavam o reencontro entre mãe e filho após seis décadas separados. Achamos que essa seria uma história de vida interessante para compreender que embora os processos migratórios sejam sociais, diferenciando-se entre grupos sociais, tendo causas estruturais econômicas, políticas ou culturais, eles também

1 Os principais jornais locais destacaram o retorno do Renato. A notícia foi destaque tanto na mídia impressa quanto nos canais de televisão. 
são marcados pela experiência singular dos sujeitos desses processos, ou seja, os migrantes. Entendemos ainda que a história de vida de Ramiro, tornada pública através da mídia local, estaria de acordo com os objetivos e proposta dessa publicação. Assim, pretendemos compreender como ele narra sobre a experiência de migrar e as relações com a família. Para tanto, nos fundamentamos na metodologia da História Oral. O relato que serve de base para o presente artigo é resultado de uma entrevista com Ramiro gravada digitalmente, com uma hora e cinco minutos de duração, realizada no dia 29 de setembro de 2013, e que transcrita resultou em um texto de 19 páginas.

A entrevista que tivemos a oportunidade de fazer com Ramiro no período mencionado foi uma entrevista aberta, sem um roteiro definido (QUEIROZ, 1988; ALBERTI, 2005; FERRREIRA; AMADO, 2013), em que motivamos Ramiro a narrar sua experiência migratória. Além desse material, também utilizamos uma entrevista com sua mãe, Maria José, de 95 anos, realizada no dia 30 de setembro de 2013. Embora o artigo se fundamente primordialmente na entrevista com Ramiro, também iremos mobilizar algumas memórias da mãe quando trata de narrativas que são versões diferenciadas de fatos, eventos e experiências. Entendemos a narrativa como um texto produzido pelo trabalho da memória (HALBWACHS, 1990; BOSI, 1987; POLLAK, 1992), na qual falar sobre o passado é revisitá-lo a partir do que o indivíduo é no presente.

A memória, sendo uma releitura do passado a partir do presente, é marcada pela posição social do sujeito que narra e por suas percepções sobre a própria vida. Assim, o indivíduo, ao falar sobre sua vida, está construindo uma imagem para si mesmo e para os outros, que podem ser a família, o pesquisador ou outros membros de suas redes de relação. Assim, narrar o passado é mobilizar símbolos identitários, como nos ensina Pollak (1992, p. 204):

A memória é um elemento constituinte do sentimento de identidade, tanto individual como coletivo, na medida em que ela é também um fator extremamente importante do sentimento de continuidade e de coerência de uma pessoa ou de um grupo em sua reconstrução de si.

A relação entre o ato de narrar e a construção de identidades é analisada por Silva e Menezes (1999) em um artigo sobre as narrativas dos migrantes temporários. As autoras se fundamentam em Walter Benjamin (1987), que compara a arte de narrar à arte do trabalho artesanal, em que não há separação entre produtor e produto do trabalho. A narrativa diz respeito às mãos, aos olhos e à alma. Ramiro, ao mobilizar as narrativas da saudade, sofrimento e tristeza, está escrevendo um texto com suas mãos, olhos e alma, ou seja, trata-se de uma narrativa em que se imprime a experiência prática da vida, as percepções e seus sentimentos. Benjamim distingue dois conceitos para compreender as 
transformações da narrativa na modernidade: "experiência e vivencia". Experiência é o conhecimento acumulado, que se prolonga no tempo, como em uma viagem. Vivência é a impressão forte que precisa ser assimilada às pressas e possui efeitos imediatos.

As autoras se referem ainda a dois tipos de narrativas: as que são manifestas em palavras e as que são invizibilizadas na oralidade ou na linguagem escrita, mas são vivenciadas por meio do silêncio. Os combatentes de guerra geralmente preferem o silêncio. Isso não significa que eles não tenham nada para contar, na verdade eles mantêm o silêncio sobre os horrores vividos: "Silêncio entendido não como forma de esquecimento, mas como um ato de resistência. Estas pessoas estariam se resguardando de outros possíveis sofrimentos e constrangimentos." (SILVA; MENEZES, 1999, p. 7).

O silêncio é compreendido por Pollak (1989) como "memória envergonhada". Ele relata sobre os significados do silêncio entre as pessoas que vivenciaram trauma de guerra: "Relatar as condições degradantes seria humilhar-se, e ferir a dignidade pessoal perante a família e a comunidade. Essa memória não se exterioriza.” (POLLAK, 1989, p. 8).

A experiência de migrações de Ramiro expressa uma ruptura, temporária ou física, dos laços com a família. As pesquisas que temos desenvolvido com migrantes envolvidos em diferentes situações de deslocamentos têm revelado que na maioria das situações não há uma ruptura dos laços de família, mas as trajetórias migratórias são tecidas nas e pelas redes familiares e de amizade. Os que migram e os que ficam tecem cotidianamente, e ao longo de sua trajetória, trocas econômicas e simbólicas.

Embora Ramiro tenha permanecido seis décadas sem se comunicar com a família, mostraremos como em sua narrativa essa ausência não significou uma perda da relação afetiva com os familiares.

A família se tornou um ausente presente através de seus sentimentos e de seu imaginário. Essa vivência das migrações está bem formulada por Sayad (2000):

O retorno é naturalmente o desejo e o sonho de todos os imigrantes, é como recuperar a visão, a luz que falta ao cego, mas, como cego, eles sabem que esta é uma operação impossível. Só lhes resta, então, refugiarem-se numa intranquila nostalgia ou saudade da terra [...]. A noção do retorno estaria no centro do que pode ser ou do que desejaria ser uma antropologia total do ato de emigrar e de imigrar: antropologia social, cultural, política, na qual se introduz eficazmente a lembrança da dimensão universal do fenômeno migratório (SAYAD, 2000, p. 11-12).

A noção de retorno tem duas dimensões, uma ontológica, ou seja, constituinte da própria construção da identidade do migrante, e outra que é epistemológica, que envolve as dimensões econômica, cultural, social e política. 
Em Sayad (2000), a noção de retorno expressa as ambiguidades, contradições e tensões entre as condições objetivas definidas pelas estruturas socioeconômicas e os sonhos, desejos, expectativas dos migrantes. Assim, embora as condições objetivas não lhes permitam retornar à sua terra natal, o desejo de retornar mantém-se vivo como um sinal da esperança de dias melhores, de estar perto de parentes, vizinhos e amigos que estão fisicamente distantes.

Esse é um dos numerosos paradoxos da imigração: ausente onde está presente e presente onde está ausente. Duplamente presente - efetivamente aqui e ficticiamente lá - e duplamente ausente - ficticiamente aqui e efetivamente lá - o imigrante teria uma vida dupla, que ultrapassa e que é diversa da oposição tradicional entre vida pública e vida íntima: uma vida presente, banal, cotidiana, vida que pesa e enreda, vida segunda, ao mesmo tempo cronológica e essencialmente secundária; uma vida ausente, figurada ou imaginada, rememorada, uma vida que foi primeira cronologicamente e que permaneceu primeira, essencial, afetiva e efetivamente, e que, sem dúvida, voltará a sê-lo um dia (Ibid., p. 20).

A narrativa de Ramiro, nos termos de Sayad (2000), pode ser compreendida como uma vida ausente, mas imaginada, rememorada. A saudade da mãe e dos irmãos como narrativa predominante se revela como uma "experiência primeira cronologicamente e permaneceu primeira, porque é a essencial, afetiva e efetivamente voltará a sê-lo um dia" (Ibid., p. 20). O retorno após sessenta anos concretizou efetivamente o elo afetivo vivenciado como ausência, sofrimento e tristeza.

Propomos refletir no presente artigo sobre algumas questões que emergem da experiência migratória de Ramiro. O que motivou a saída? Por que nosso "narrador" se desligou, não contatou a família? Como ele narra a ausência e distanciamento da família? O que e como fala sobre sua rede de relações sociais no Rio de Janeiro e em São Paulo? Quais marcadores simbólicos são mobilizados na narrativa para a construção de sua identidade?

Nosso encontro foi intermediado por um irmão dele, Ozéas Jordão, professor de Geografia da Universidade Estadual da Paraíba. Nosso primeiro contato com Ozéas se deu através de troca de e-mails, nos mostramos interessados pelo registro dessa história e sugerimos marcar um encontro com seu irmão. Em um segundo momento, passamos a nos falar por telefone. Tudo tinha de ser rápido porque o tempo de permanência do irmão em Campina Grande era muito curto, ficaria apenas cinco dias. Ramiro havia chegado na quinta-feira, e a entrevista foi realizada no domingo pela manhã, no antigo Museu Assis Chateaubriand, no centro de Campina Grande.

Além das entrevistas, também utilizaremos algumas reportagens veiculadas nos jornais e sites de notícias sobre o motivo da saída de Ramiro e o reencontro com sua mãe. 
Vale reforçar que a mídia divulgou amplamente esse reencontro familiar. Além disso, realizamos a observação direta do convívio com a família de Ramiro, que ocorreu entre os dias 29 e 30 de setembro de 2013, em função da realização das entrevistas.

Metodologicamente, trata-se de um exercício que reúne um pouco de etnografia, análise de notícias veiculadas nos meios de comunicação e História Oral. Estruturamos a nossa análise em três partes. A primeira tratará sobre a saída, as motivações e os desafios do migrar, a segunda destacará a experiência de vida de Ramiro fora do lugar de origem e sua narrativa sobre a distância, a ausência e a falta de contato com a família, e a terceira parte analisará o reencontro com sua família, especialmente com sua mãe.

\section{A saída: "Os incomodados que se mudem..."}

A maioria dos estudos sobre a migração evidencia que as motivações são econômicas, como busca de trabalho e melhora de vida (LOPES, 1976; DURHAN, 1978; MENEZES, 1985), mas a migração também acontece por questões afetivas relacionadas a conflitos com cônjuges, pais, irmãos ou outros. Um conflito familiar teria sido um dos motivos que levaram Ramiro Jordão a deixar a cidade de Campina Grande no início da década de 1950. As reportagens publicadas em blogs, programas de televisão e jornais impressos afirmavam um desentendimento com os pais por causa de um namoro proibido. A notícia foi divulgada pela família na mídia em virtude do reencontro décadas depois:

Ramiro foi embora do Sítio Bela Vista, no município de Queimadas, aos 17 anos, e no estado de São Paulo construiu uma vida inteira longe dos familiares. O motivo da partida foi um desentendimento familiar por causa de um namoro que, na época, foi proibido pelos pais ${ }^{2}$

Em sua narrativa, Ramiro coloca em segundo plano essa questão do "desentendimento familiar", mas não nega sua existência. Ele admite sua existência, mas afirma que não teria sido apenas aquela questão que o levou a migrar. Do mesmo modo, aquele "desentendimento" não teria sido a principal razão dele não ter retornado à sua terra natal.

É, eu tive, eu tive, vamos dizer assim. A minha primeira namorada, eu tive outras namoradas, mas uma me cativou muito, assim, na vida sentimental, e eu acho que ela até sofreu mais do que eu, pelo que o pessoal me conta, mas não foi bem isso aí não. Tem é... Tem um a ver. (JORDÃO, 2013).

2 Jornal da Paraíba, edição online, sexta-feira, 27 de setembro de 2013. 
Para resolver essa questão colocou em prática um ditado popular considerado por ele extremamente importante: “'Os incomodados que se mudem.’ [...] É um dizer que as pessoas falam, e eu acredito muito nisso e boto isso em prática, toda vida botei. 'Os incomodados que se mudem'.” Perguntado sobre o que o incomodava, Ramiro não culpa os pais, não reconhece na própria família um problema para aquele relacionamento anteriormente vivo.

Não era ela. Não eram meus familiares, mas os familiares dela eram muito incomodados com isso. Quer dizer, eles achavam que não tinha como fazer isso, como dar prosseguimento àquele namoro, àquela coisa. Ficaram muito incomodados, e eu tomei isso como uma afronta. E segui esse ditado, que pra mim é uma lei: “Os incomodados que se mudem”, e eu me mudei (risos).

Não sabemos se por vergonha, esquecimento ou peso na consciência, a mãe de Ramiro não trata desse "desentendimento" em sua narrativa sobre a saída do filho de casa. Diz apenas que Ramiro foi para o Rio de Janeiro para a casa de irmãos, depois mudou pra São Paulo e não deu mais notícias. Ele também não mencionou por que a família de sua namorada não aceitar o namoro, e logo se destaca algo comum nas narrativas migratórias: o desejo de encontrar trabalho e melhorar de vida. Para a mãe de Ramiro, a migração foi favorecida pela existência de redes familiares, ${ }^{3}$ já para Ramiro, o que teria motivado seu "projeto migratório" foi aquilo que Sayad (2000) define como o elemento constitutivo da condição do migrante: o trabalho.

O trabalho é concebido de maneira positiva pelo Ramiro, que confessa ter começado a trabalhar desde cedo, quando tinha em torno de 16 a 17 anos. Foi através do trabalho que ele diz ter "tomado conta da própria vida". Isso também vai estar presente na fala da mãe: "Ele era trabalhador. Desde pequeninho inventou de comprar ovo para revender, depois inventou de comprar galinha, depois inventou de comprar bacurim nos sítios em Queimadas e vendia em Campina Grande." ${ }^{4}$ Mas a Campina Grande dos anos 1950 não era um lugar de bons empregos e o trabalho tinha uma finalidade muito prática na vida daquele garoto: "Assumir a própria responsabilidade." Trabalho como forma de independência. Filho de agricultores, Ramiro era o quarto filho de uma família de dezesseis irmãos.

3 A importância das redes familiares e de amigos é um aspecto mencionado em diversas pesquisas sobre migrações. (DUHRAN, 1978, MENEZES, 1985, 2002).

4 Essa narrativa sobre a experiência de iniciação no trabalho na fases de infância e juventude confirma algumas pesquisas que indicam a importância do trabalho na socialização de jovens entre famílias do meio rural e das classes populares na região Nordeste. Sobre esse tema, ver Alves e Menezes, 2012; Menezes, Malagodi e Marques, 2008; Menezes, 2002; 2006. 
É bom lembrar que a década de 1950 foi a década do boom das migrações do Nordeste para o Sudeste, sendo que da região do Agreste da Borborema, onde se situa o município de Campina Grande, migrava-se principalmente para o Rio de Janeiro (MENEZES, 2002). Talvez por isso o primeiro destino do Ramiro tenha sido a capital carioca. Foi como ajudante de caminhoneiro, carregando e descarregando o veículo, que ele desembarcou em São Paulo em 1953.

Sair de casa representou o rompimento com os laços familiares. "Fui prolongando o tempo, prolongando, prolongando [...] a ponto de perder contato". Somado a isso ainda estava a dúvida quanto ao destino que os pais haviam tomado. "Fiquei até com medo de vir pra cá porque eu pensava assim: 'papai não está mais lá, papai não está vivo, mamãe não está' [...]. Eu fiquei com medo de chegar aqui e ficar perdido também que nem chegava no Rio de Janeiro, São Paulo.” Mas na compreensão dele isso aconteceu de forma natural. O natural aqui é entendido como resultado das condições estruturais de comunicação da época. As dificuldades de acesso à telefonia fixa, por exemplo, é um dos pontos destacados por ele:

Naquela época, os meios de comunicação eram os piores que tinha. É, não tinha esse negócio de celular, até telefone era a coisa mais difícil que tinha. Nas casas não tinha telefone. Onde tinha era num posto de saúde, posto policial... Eram os telefones que existiam na época. Mas eu, como eu ia ligar para uma pessoa aqui se não tinha o telefone? Muito difícil. Até que eu cheguei no Rio de Janeiro, para São Paulo... Aí piorou.

Algo bastante comum nas narrativas dos viajantes é que o mundo ensina. As experiências dos migrantes ampliam o horizonte de sua visão de mundo. Eles vivenciam diferentes atividades de trabalho, moram em diferentes lugares, convivem com pessoas de diferentes posições sociais, lidam cotidianamente com situações imprevisíveis e desconhecidas. Nos termos de Walter Benjamin (1989, p. 198), os migrantes, como os viajantes, são narradores que tem muito a contar, ou seja, tem um conhecimento prático construído ao longo de sua trajetória de vida.

O discurso de Ramiro também reforça aquela ideia de que o melhor professor é o mundo, é a vida: "Hoje em dia eu sou mais, vamos dizer assim, mais culto do que naquela época." A vida "fora de casa" seguiu seu curso, e Ramiro também procurou viver isso com naturalidade.

\section{A vida fora de casa: "Uma vida oprimida pela saudade..."}

Embora o Ramiro não tivesse contato com sua família de origem, ele não estava isolado no mundo, mas construiu outras redes sociais que lhe conectaram socialmente 
nos espaços e tempos onde trabalhou, morou e se divertiu. Casou, teve filhos, constituiu família e passou por uma situação delicada que ainda provoca alteração na voz quando acionada pela memória. É um caso relacionado a seu primeiro filho, fruto de um relacionamento com uma empregada doméstica de um casal de portugueses em São Paulo. Quase quarenta anos depois, a atitude da ex-namorada, mãe de seu filho, é lembrada com tristeza.

Eu cheguei lá, tive uma mulher, empregada de um português lá. Essa coisa também me abala um pouco, mas só que é uma coisa que eu tenho superado da melhor forma possível [...] foi um trauma muito grande, porque quando eu arrumei essa mulher, e ela teve um filho, o português, patrão dela, morreu, os familiares foram para Portugal e levaram meu filho.

Ele chegou a conviver com o menino até os oito anos de idade, mas depois foi informado pela mãe de seu filho que o menino havia sido levado para Portugal. Ao se referir aos portugueses que levaram seu filho, como forma de suprir a ausência de uma pessoa que morreu, afirma que "isso é bobagem", que cada pessoa cumpre um papel importante e fundamental em nossas vidas, e que essas pessoas são insubstituíveis. "Não existe esse negócio da pessoa perder uma mãe e botar outra, perder uma mulher e botar outra, perder um filho e botar outro... não existe. Isso não existe".

Até o nome do filho é dúvida para Ramiro:

Não sei de tudo, o nome dele é Edson, agora o sobrenome... Certamente está com o sobrenome deles. Não tem como, fica muito difícil. É tanto que eu nem procuro nem entrar em detalhe dessas coisas aí, e se alguém vier me aconselhar, acho até que eu nem gosto.

Também atribui a este caso características de um crime. Como se o filho tivesse, de fato, sido roubado. Para realizar tal empreendimento, os portugueses enganaram a mãe do menino, dizendo que mandariam buscá-la. Aborrecido com a situação, Ramiro perdeu o contato com a mãe de seu primeiro filho e também não sabe informar se os portugueses cumpriram com o prometido e a levaram para Portugal. Disse que mesmo com tantos problemas na vida, nunca chorou, mas lamentava porque, para ele, quando as pessoas choram, liberam mais o sofrimento.

As poucas vezes que os olhos lacrimejaram, durante a entrevista, ele fez questão de culpar os óculos que estavam vencidos. "Eu choro assim forçado porque eu estou aqui com esses óculos, e não está com o grau certo para mim, eu não estou nem usando. Então estou forçando muito a vista, aí eu choro, mas é forçado". 
Vale destacar também que expressar os sentimentos através do choro não é algo intrínseco à natureza humana, mas uma forma de expressar as emoções socialmente e historicamente construída. Assim, em uma sociedade machista e patriarcal, para as mulheres o choro é permitido, é uma ação facilmente mobilizada para expressar emoções femininas, enquanto para os homens o choro configura-se como vergonhoso, simbolizando fraqueza. ${ }^{5}$

Ramiro fez questão de deixar claro que sempre teve alguém para dividir os bons momentos, como ir ao cinema: "Ah, eu nunca paro de arrumar gente não. Eu sempre tenho uma pessoa para ir ao cinema (risos). Para o cinema só eu nunca vou. Posso até ter ido, mas não lembro. Eu não vou só para o cinema, de jeito nenhum (risos).” Isso também pode está dentro dessa construção social de sua identidade perante o outro: mesmo aos 77 anos, continuava jovem e viril.

Mas quando o migrante passa muito tempo longe de sua terra natal, paga um preço muito alto por isso. No caso específico do retorno desse migrante, percebemos que o sentimento de vergonha toma conta de alguns momentos da entrevista. Há um visível sentimento de culpa em sua narrativa oral:

Distante da família... E aquele período vai traumatizando. Dá uma saudade, principalmente da mãe, né. E o cabra vai se perguntando: mas como é que o cabra pode fazer uma maldade dessa com a própria mãe? Aí o cabra fica assim, meio envergonhado.

Ao mesmo tempo, ele também não tem certeza de como seria esse retornar. Não sabia e temia pelo que o esperava. As incertezas não estão mais no lugar de destino, elas agora fazem parte da própria origem. Voltar para casa era ir ao encontro das dúvidas, das angustias, do incerto e dos fantasmas do passado. Não havia nenhuma garantia de que seria bom retornar. Para resolver tal dilema, coube ao migrante protelar, e quanto mais o tempo passava, mais os laços se distanciavam.

Além desses elementos enumerados por Ramiro, outros se somam a essa dificuldade de retornar, principalmente a longa distância e a dificuldade de acesso aos meios de comunicação. Além disso, quem migra deseja ter sucesso, melhorar de vida, e nessa espera vai se protelando o retorno. Em Sayad (2000), encontramos o retorno enquanto perspectiva econômica. Uma espécie de sonho quimérico de todos os migrantes de retornarem ricos para a sua terra. E esse retorno só teria sentido quando o grupo de onde ele migrou reconhecesse sua condição de "vitorioso", de alguém que conseguiu "dar a volta

5 Não temos condições de aprofundar nesse artigo a análise do choro, apenas nos limitamos a registrar que as emoções são socialmente construídas, assim como nos ensina Marcel Mauss (1980). 
por cima" e superar aquela condição desfavorável em que se encontrava antes de efetivar o deslocamento.

Voltar rico efetivamente ou somente em aparência conta talvez mais que a realidade, consiste em, de certa forma, querer fazer uma revanche social, mas também tornar-se claro para si e para os outros o sentido da sua emigração e de sua ausência, para que estas não sejam, uma e outra, pura vaidade, falência total, ato gratuito e, entretanto, absurdo, ato desprovido de qualquer significado, pois só há sentido e razão no reconhecimento que lhe atesta o grupo. (SAYAD, 2000, p. 16)

A ideia de que o migrante deve retornar como vitorioso também alimenta o imaginário das migrações, ou seja, a ideia de que para melhorar de vida é preciso sair pelo mundo. Fontes (2008), em seu estudo sobre os migrantes nordestinos na região leste do município de São Paulo, mostra o caso de um trabalhador mineiro que ao retornar da lavoura à sua terra de origem, em 1949, estava com a boca cheia de ouro. Isso era motivo para atrair a atenção e a curiosidade daqueles que nunca haviam deixado sua terra natal. No caso particular de Ramiro, enquanto o retorno não era possível, as redes de contatos, estabelecidas no destino, davam ao migrante uma sensação de conforto e uma garantia que o faziam "prolongar o tempo" e até mesmo tirar de sua agenda esse retorno para a casa de sua mãe.

Onde é que eu tava se não fosse grande coisa, se não fosse boa coisa, mas eu tava com facilidade de arranjar um emprego de me comunicar com as pessoas, dono de firma e tal. E fui tocando o barco. Fui tocando o barco, fui tocando... Pensei que não, foi que nem um sonho. Na época que eu tive contato com o Ozéas, eu já tava com quase 70 e tantos anos já... (Silêncio) Aí foi aquele negócio, ele disse: "Eu vou te buscar." Aí eu fiquei.

Ao se referir à categoria "saudade", Ramiro Jordão disse que saudade também mata, e é uma morte muito mais dolorosa, porque a fome mata em poucos dias, e a saudade mata aos poucos:

A vida oprimida pela saudade eu acho que é... É uma vida oprimida quase que pela fome, entendeu? A fome, no caso essa fome de alimentação material, mata, mas a saudade também mata, só que a fome a qual eu the falei mata rápido, aquilo é passageiro, agora uma fome que se prolonga por 30, 40, 50, 60 anos com aquela fome, aquele desejo, aquela saudade é a coisa mais difícil que a pessoa tem que enfrentar na vida. Experiência própria. 
Mas a condição do migrante continua muito forte para Ramiro. Mesmo aos 77 anos ele se orgulha de ser um empregado, de poder desenvolver suas atividades, ainda que aposentado. "Eu trabalho, sou empregado. Eu ganho uma mensalidadezinha né, de beneficio do governo, mas trabalho. Trabalho normalmente como qualquer pessoa de 20 , 30 anos."

Embora Ramiro enfatize em sua narrativa a ideia de "prolongamento do tempo", o fato é que tempo não parou. Ele seguiu seu curso, e muita coisa aconteceu entre 1953 e 2013. Entre as consequências de um tempo que não dá trégua nem perdoa ninguém, estão os lamentos por não encontrar mais aqui muitos de seus amigos de infância. "Encontrei muitos, mas faltaram muitos também, muitos já estão na presença de Deus. Então, [isso] me deixou assim, meio triste né".

\section{O retorno: "Bença mãe, me perdoa!"}

Sessenta anos se passaram entre essa primeira viagem e um retorno acontecido em outubro de 2013, fruto de um esforço de um de seus quinze irmãos em localizá-lo Brasil afora. Mas quando esse dia chegou, Ramiro deparou com um misto de sensações que incluíam decepção, emoção e saudade: "Eu achei até que ia passar por decepção, não foi uma decepção, foi uma grande emoção da maneira como me receberam né, inclusive minha mãe está lá." Ele segue explicando esse momento tantas vezes adiado: "Aí foi quando eu, naquela expectativa de decepção... Foi uma grande emoção. Satisfação e emoção. E essa emoção superou aquela coisa que traumatizava a minha vida, que era saudade. Para mim foi um alívio".

De repente, foi como se nada que ele houvesse imaginado de fato acontecesse, e o reencontro desse a ele a sensação de juventude novamente. Como se o tempo tivesse parado:

Então foi aquela a expectativa que eu tive, que eu tinha, no caso, de chegar aqui e encontrar uma coisa, [e] encontrei outra completamente diferente, mais confortável, digamos assim, para minha presença, minha pessoa, que a minha pessoa... Eu achei que até eu fui muito forte para suportar tudo aquilo lá. Eu tive momentos em que eu disse: "Acho que vou desmaiar aqui, de tanto abraço, tanta emoção.” Então para mim foi um momento muito, muito especial, e hoje eu posso dizer para você que aquele negócio, aquele trauma, a saudade, aquilo lá acabou. Estou como se fosse um menino de 18 anos, 20 anos, da minha época que morei aqui.

Ramiro foi recebido com festa. A mãe dele, aos 95 anos, o esperava ansiosa no saguão do Aeroporto João Suassuna. Ramiro reafirma algo amplamente explorado pela mídia sobre o reencontro no aeroporto: que a primeira coisa que falou para sua mãe, logo 
que desembarcou, foi: “Bença mãe, me perdoa!”. O perdão, segundo ele, foi pela ausência, por tê-la feito sofrer com a falta de notícias suas. Mas ele disse que nunca abandonou a família. Sempre teve saudades de todos, mas não sabia como encontrá-los novamente. A saudade é uma justificativa para si mesmo e para a família, é um acerto de contas entre o passado e o presente, como revela o sentimento em relação à família quando partiu, durante sua ausência e atualmente.

Sobre o namoro proibido, razão que teria feito que ele migrasse, Ramiro afirma que a história não foi tão simples. Sua família não era contra, mas a família dela. A antiga namorada seguiu sua vida: casou, teve filhos e hoje é falecida. Ele esteve na casa dela, conheceu o viúvo e conversou com as filhas. Ficou surpreso com a recepção de todos.

Pelo jeito, elas tinham conhecimento da amizade que eu tinha com a mãe delas, não foi possível a gente concluir um casamento... Então elas, sem eu pedir nada, foram lá dentro, trouxeram uma foto dela, ela já meio abalada... É a vida né? Então foram lá, trouxeram a foto e me mostraram... Se me mostrassem e perguntassem, eu não conhecia. A foto era completamente diferente do que ela é, mas essa coisa tá superada.

A chegada de Ramiro foi festejada, e era digna de um almoço especial, com a mesa farta. Toda a família o esperava, incluindo muitas pessoas que ele nem chegou a conhecer.

Rapaz, não dá para te falar. Era tanta coisa. E uma coisa que me chamou muita atenção, porque fazia muito tempo, muito tempo [...] foi carne de bode. Feijão verde, fava verde, farinha de mandioca, lá tem também, mas não é boa que nem aqui. É... Sei lá, era tanta coisa. Coisa que nem realça numa mesa, mas tinha, bolo... Bolo não é nem almoço, é lanche, é café, mas tinha. Bolo é uma coisa para fazer outro tipo de recepção, mas tinha. Sei lá, se você me perguntar ou alguém me perguntar o quê que tinha, eu vou dar a mesma resposta: "Não sei." Tinha tudo, e emoção!

O retorno, em vários momentos de sua narrativa, ganha contornos de renascimento. Reencontrar a família depois de tanto tempo carrega a simbologia da criação:

Eu estou me sentindo como se eu tivesse nascido agora. Eu estou vendo a minha mãe naquela idade, para mim eu estou vendo a minha mãe me dando de mamar. Aquela alegria que ela tem de estar me vendo supera qualquer expectativa, coisa muito bacana.

Ele admite que não gosta de lidar com as memórias nem de tratar desses assuntos que o fizeram migrar, pois considera uma "história longa", de difícil narrativa. 
Ao retornar, Ramiro também não encontra mais o pai, falecido há muito tempo. Mas a morte, para ele, embora não seja confortável, possibilita uma relação menos desgastante com a saudade. Morrer se configura parte de um processo natural e a aceitação da ausência por causa da morte é tolerável. "Ele morreu porque tinha que morrer, mas morreu de morte natural. A morte, pensando bem, é uma coisa superável. Quando você tem saudade de uma pessoa e sabe que ele morreu, estaciona, estaciona..."

Embora se perceba que os sentimentos da saudade e alegria estejam presentes ao longo de sua narrativa, ele fica em silêncio quando se trata do sentimento de medo. Ele não se considera uma pessoa medrosa e, por isso, nunca temeu reencontrar a família um dia. "Eu não sou muito medroso. Eu já passei um bocado ruim na vida assim... No que diz respeito a medo e coragem e eu já... Eu mesmo faço as minhas apurações dos casos e eu vi que eu tinha mais coragem do que medo." Embora a coragem se sobreponha ao medo, logo em seguida ele se autodenuncia: "Eu não tenho muito medo". Para ele, que não se considera uma pedra, é mais importante lidar com palavras como emoção, alegria e saudade do que atribuir as incertezas da vida ao medo. "Eu faço o possível para não exagerar nada, porque se eu não fosse prevenido, talvez num momento daquele lá [do reencontro com mãe] me dava um colapso, uma coisa." Mas não se emocionar ou não expressar essa emoção pode ter para ele um preço: "E eu tenho um problema comigo, que já aconteceu várias vezes: eu não choro. Eu não choro, então isso é fácil de dar um... dar uma pane (risos). A maquininha dá uma pane, não é verdade?" Aqui, Ramiro faz referência à possibilidade de um infarto causado por ele não deixar as emoções fluírem.

Então, mas esse negócio de quem não chora eu acho que prejudica a vida sentimental das pessoas. As pessoas que choram geralmente têm mais facilidade a resistir à angustia, à saudade, aos transtornos da vida e... Tem gente que se emociona e chora, tem gente que sente uma surpresa desagradável e chora, se morre uma pessoa... Eu não tenho isso. Não sei por que, é da minha natureza.

Mas não está entre os seus planos permanecer distante dos parentes por mais tanto tempo: "Eu não gostaria que isso viesse a acontecer novamente, Deus me livre!" Um dia antes de partir, já fazia planos de voltar. Queria acompanhar a festa do padroeiro de sua cidade natal, Queimadas, que é um município vizinho de Campina Grande. Sessenta anos depois, ele já sabe que não encontrará a mesma festa:

Em janeiro tem uma festa de rei em Queimadas né, que é a cidade, na qual eu nasci, e eu vou fazer o maior esforço para vir em janeiro, acho que é dia cinco parece [...]. Hoje a festa está de uma maneira diferente. É um para lá outro para cá com seu namorado, as minhas irmãs com os 
namorados e eu com a minha namorada, e hoje não, hoje a gente vai assim para se reunir em algum lugar, tomar um sorvete e, vamos dizer assim, observar a festa, curtir a festa, só.

Nosso narrador se refere à festa de São João de Campina Grande, que ele sempre viu pela televisão, mas desconhece pessoalmente. Embora diga que se sentia orgulhoso em ver a cidade sendo divulgada pelo rádio e pela televisão, a memória que ainda tem na cabeça é de uma tímida cidadezinha do interior com seus folguedos improvisados.

Não, ninguém falava em grandeza, isso aqui era uma cidade pequena na época, 60, 70 anos atrás. Mas isso aqui era uma cidade pequena, não tinha essa divulgação de São João que nem hoje tem, Campina Grande, Caruaru e outras cidades aqui, tem aquela informação de rádio e televisão que deixa a gente assim... orgulhoso né, porque tudo que é grande na nossa cidade, no bairro ou na vila, seja onde for que você more, você se orgulha disso, isso aí não precisa falar que não... Todo mundo se orgulha disso.

Ramiro Jordão, em seu trabalho da memória, descreve em detalhes alguns momentos vividos há dezenas de anos, mesmo assim reconhece as limitações advindas dessas lembranças: "Nunca, nunca, nunca você vai, numa horinha de conversa, conversar a respeito de história de 60, 75 anos de vida". Para ajudar em sua tese de que temos uma memória curta, ele utiliza o exemplo de leitores de jornais: "É como se você pegasse um jornal e lesse $10 \%$ das manchetes. Só. Só manchete, sem ler o jornal, [...] e depois o cara falar a respeito daquele jornal amanha, você diz: você viu aquele jornal? Rapaz, acho que eu vi. Não é?”.

Embora Ramiro insista em justificar que sua memória é curta e que não seja capaz de relembrar tudo, sua narrativa é escrita com as mãos, olhos e alma orientadas por uma rica e diversificada experiência de vida de um migrante que vive a dupla condição de vivenciar os ausentes por meio de sua imaginação e de seus sentimentos.

\section{Considerações finais}

A metodologia da História Oral foi nosso guia na construção e interpretação dessa narrativa de vida. Foi na tentativa de reconstruir esse longo espaço de tempo vivido longe da família e da terra natal, que ouvimos atentamente a história desse migrante que fez questão de deixar claro aos pesquisadores: "A gente não lembra tudo assim, [...] que 65 anos de história, é... Você não vai conseguir lembrar de uma manchete de jornal que saiu hoje, amanha você não vai lembrar, imagina lembrar 60 anos de história?" Mas Ramiro possui uma memória bastante singular, uma vez que consegue reconstituir momentos importantes vividos ainda na Paraíba e outros pelo mundo afora. 
Como analisamos no desenvolvimento do artigo, após 60 anos, o passado é interpretado em sua narrativa a partir de sua identidade no tempo presente. Sua narrativa inscreve a construção de uma imagem social positiva para si mesmo e para o que estão em suas redes de relações como os familiares e os amigos. A memória, ora nítida e verbalizada, ora esquecida, envergonhada ou silenciada (POLLAK, 1992), é também perceptível em sua narrativa, especialmente quando se trata dos relatos sobre o desentendimento familiar que teria motivado sua migração. Vale destacar que o ato de migrar e o longo tempo de ausência também não foram capazes de romper definitivamente as relações de afeto entre Ramiro e sua família. Mesmo distante da família, ele afirma mantê-la presente nas lembranças e em seu imaginário. Retornar seis décadas depois representou o reestabelecimento dos elos afetivos iniciados na infância e juventude.

A experiência migratória de Ramiro, ao ser marcada pela longa ausência da família, questiona a prática social corrente em que as relações entre os membros da família, continuam sendo tecidas ao longo da experiência migratória de indivíduos e famílias. Nos locais onde residiu, São Paulo e Rio de Janeiro, Ramiro construiu laços sociais e redes de contatos que significaram suas redes de sociabilidades e afetividade. Muito tempo longe de casa teria transformado o familiar em estranho, a segurança em incerteza. No tempo de ausência, ele foi se construindo em diversas redes de relações pessoais, adquiriu amizades, casou e teve filhos. Além disso, sua identidade também se constrói por uma forte e positiva compreensão do trabalho.

A expectativa do retorno foi vivenciada através "do prolongamento do tempo", ideia repetida ao longo de sua narrativa que indica o desejo de retorno vivenciado permanentemente, mas que foi sendo adiado pelas contingências do cotidiano da vida. Retornar após tantos anos é reviver no tempo: "É como se o tempo tivesse estacionado. Me sinto como uma criança nos braços da minha mãe". É dessa forma, ora negando, ora reforçando pedaços da memória, que Ramiro vai construindo sua narrativa, a fim de assegurar uma imagem pessoal e socialmente positiva. Assim ele produz um acerto de contas consigo e com a família, ao afirmar que ela nunca esteve completamente ausente, pois sempre estivera presente em seu imaginário e em seus sentimentos.

\section{Referências}

ALBERTI, V. Manual de história oral. 3. ed. Rio de Janeiro: FGV, 2005. 236p.

ALMEIDA, G. M. R.; BAENINGER, R. Modalidades migratórias internacionais: da diversidade dos fluxos às novas exigências conceituais. In: XXVIII CONGRESSO INTERNACIONAL DA ALAS, 6 a 11 de setembro de 2011, UFPE, Recife. 
BENJAMIN, W. Magia e técnica, arte e política. 3. ed. v. 1. São Paulo: Brasiliense 1987.

BOSI, E. Cultura e desenraizamento. In: BOSI, A. (Org.). Cultura brasileira: temas e situações. São Paulo: Ática, 1987. p. 16-41.

DURHAN, E. R. A caminho da cidade: a vida rural e a migração para São Paulo. 2. ed. São Paulo: Perspectiva, 1978.

FERREIRA, M. de M.; AMADO, J. (Orgs.). Usos e abusos da história oral. 8. ed. Rio de Janeiro: FGV, 2013.

FONTES, P. Um Nordeste em São Paulo: trabalhadores migrantes em São Miguel Paulista (1945-66). Rio de Janeiro: FGV, 2008.

HALBWACHS, M. A memória coletiva. São Paulo: Vértice, 1990.

JORDÃO, R. [set, 2013]. Entrevistador: Jurani O. Clementino, UFCG, 2013. Gravador digital.

LOPES, J. R. B. Desenvolvimento e Mudança Social. 3. ed. São Paulo: Nacional, 1976

MAUSS, M. A expressão obrigatória dos sentimentos. In: FIGUEIRA, S. (Org.). Psicanálise e Ciências Sociais. Rio de Janeiro: Francisco Alves, 1980.

MENEZES, M. A. Da Paraíba pra São Paulo e de São Paulo pra Paraíba (Migração, Família e Reprodução da Força de Trabalho). Dissertação (Mestrado) - Universidade Federal da Paraíba. Campina Grande: Universidade Federal da Paraíba, 1985.

História de Migrantes. Centro de Estudos Migratórios - CEM. São Paulo: Loyola, 1992. . Memórias de infância de mulheres e homens camponeses. Fortaleza: Trajetos, 2002. p. 185-207. . História Oral: uma metodologia para o estudo da memória. Revista Vivência, n. 28, p. 23-36, 2005. Relações entre pais, mães e filhas(os) em famílias camponesas: memórias de infância. Teoria \& Pesquisa, v. 49, p. 87-110, 2006.

MENEZES, M. A.; MALAGODI, E. A.; MARQUES, F. R. S. Juventude e educação em assentamentos do Brejo Paraibano. In: FERRANTE, V. L. S. B.; WHITAKER, D. C. A. (Orgs.). Reforma agrária e desenvolvimento: desafios e rumos da política de assentamentos rurais. Brasília: MDA; São Paulo: UNIARA, 2008. p. 131-150.

POLLAK, M. Memória, esquecimento, silêncio. In: Estudos Históricos, Rio de Janeiro, v. 5, n. 10, p. 200$212,1992$.

QUEIROZ, M. I. P. de. Relatos orais: do “indizível” ao “dizível”. In: VON SIMSON, O. M. (Org.). Experimentos com histórias de vida (Itália-Brasil). São Paulo: Vértice, 1988.

SAYAD, A. O retorno: elemento constitutivo da condição do migrante. Travessia, v. 13, n. esp., p. 7-32, jan. 2000.

SILVA, M. A. M.; MENEZES, M. A. Migrantes temporários: fim dos narradores. Revista Neho, n. 1, nov. 1999

SILVA, S. R. A. et al. Memórias de infância e juventude de migrantes de retorno de São Paulo a Pernambuco. RESGATE - Revista Interdisciplinar de Cultura, v. 20, p. 16-24, 2012. 